\title{
Restoration of Protected Lakes Under Climate Change: What Legal Measures are Needed to Help Biodiversity Adapt to the Changing Climate? The Case of Lake IJssel, Netherlands
}

\author{
Jonathan Verschuuren*
}

Table of Contents

INTRODUCTION

I. IMPACT OF CLIMATE CHANGE ON LAKES AND ADAPTATION MEASURES

NEEDED TO REDUCE IMPACTS

II. IMPLEMENTING ADAPTATION MEASURES TO PROTECT LAKES FROM

CLIMATE CHANGE IMPACTS: THE ROLE OF LAW

A. Ecosystem Restoration and Connectivity 270

B. Adjusted Management.

C. Assisted Colonization of Endangered Species

III. CASE STUDY: LAKE IJSSEL IN THE NETHERLANDS

A. The Creation of Lake IJssel.

B. Lake IJssel's Poor Conservation Status Exacerbated by Climate Change

* Professor of International and European Environmental Law, Tilburg University, The Netherlands (j.m.verschuuren@tilburguniversity.edu). Paper for the International Conference on Legal Opportunities for the Conservation and Restoration of Urmia Lake, Faculty of Law and Political Science, University of Tehran \& Tilburg Law School, 14 April

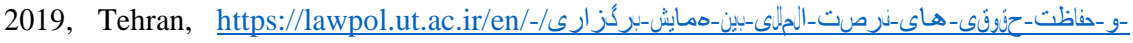
اروميه -درياجه-احياي Sections 2 and 3 of this Article use text from my chapter Regime interlinkages: examining the connection between transnational climate change and biodiversity law, in RESEARCH HANDBOOK OF TRANSNATIONAL ENVIRONMENTAL LAW (Veerle Heyvaert and Leslie-Anne Duvic-Paoli eds., Edward Elgar 2019 forthcoming). 
C. Legal Requirement to Restore the Degraded Lake IJssel ..... 280

D. Restoration Plans for Lake IJssel ...................................... 281

E. Enabling Factors for the Restoration Plans for Lake IJssel .. 284

1. Financial Budget. 284

2. The Role of the Various Authorities and Other Stakeholders Involved. 284

3. The Role of the General Public. 285

F. Assessment of the Lake IJssel Restoration Plans

\section{INTRODUCTION}

Lakes around the world are heavily impacted by climate change. Droughts, floods, higher water temperatures, changes in biodiversity, and even sea level rise all have an impact on freshwater lakes. In this Article, I look into the question of what legal measures are needed to protect lakes against these impacts with a focus on biodiversity conservation. How can law help to implement the necessary climate change adaptation measures related to biodiversity conservation for lakes?

First, I will briefly summarize current and projected climate change impacts on lakes, taking the recent Intergovernmental Panel on Climate Change's ("IPCC") Special Report Global Warming of $1.5^{\circ}$ C ("SR15") as a basis. ${ }^{1}$ The biggest problem for most lakes around the world is that their current conservation status is already poor to begin with, even in the absence of climate change. Most protected lakes are not in a favorable condition. Restoration, therefore, is much needed. Climate change further adds to the need to restore areas and connect them into an ecological network as the impact of climate change on species viability correlates with the degree of connectedness of a specie's habitat.

Connectivity conservation has been developed as an important conservation tool aimed at restoring the functional integrity of natural ecosystems such as lakes. The IPCC's SR15, as well as earlier IPCC reports, indicate that the generally needed adaptation measures are threefold: ecosystem restoration and connectivity, adjusted management, and assisted colonization of endangered species.

Second, I will discuss whether these three interventions, in theory, are required, facilitated, or perhaps obstructed under current nature

1 Intergovernmental Panel on Climate Change (IPCC), Global Warming of $1.5^{\circ} \mathrm{C}$ (Valérie Masson-Delmotte et al. eds., 2018), https://www.ipcc.ch/sr15/. 
conservation or water law. For this step, I will primarily focus on current international law, such as the Ramsar Convention on Wetlands of International Importance Especially as Waterfowl Habitat, ${ }^{2}$ the United Nations Framework Convention on Climate Change ("UNFCCC"), ${ }^{3}$ the Kyoto Protocol, ${ }^{4}$ and the Paris Agreement, ${ }^{5}$ as well as on European Union ("EU") law such as the Wild Birds and Habitats Directives ("Natura 2000 Framework"). ${ }^{6}$ I will search for provisions in these and other legal instruments that are relevant for climate change adaptation measures focusing on lakes. I will also review non-legally binding documents, such as Conference of the Contracting Parties ("COP") decisions under the Ramsar Convention addressing climate change impacts on protected lakes.

Third, I will test the findings of the previous step in a case study into Lake IJssel (IJsselmeer) in the Netherlands, a protected lake under the Ramsar Convention and the EU's Natura 2000 framework. The lake area supports very high numbers $(>300,000)$ of wintering water birds as well as endangered bird species such as ruff, bittern, avocet, and spotted crake. Lake IJssel is the biggest freshwater body in the Netherlands and is the country's main water reservoir, both for drinking water and for agricultural irrigation. Fisheries, tourism, shipping, sand extraction, artificial water level management, industrialization, urbanization, and the construction of wind farms all affect the integrity of the lake. Climate change exacerbates these human pressures. Several measures are being discussed or implemented to reduce or mitigate the human pressures on the lake. Climate change impacts, however, do not seem to play a big role in these discussions. In this third step, I will review the various documents underlying the decision making regarding Lake IJssel to assess whether the three types of adaptation measures that are suggested by the IPCC indeed are being implemented. I will also test what the role of law is or has been.

2 Comm. on Foreign Relations, The Convention on Wetlands of INTERNATIONAL IMPORTANCE ESPECIALLY AS WATERFOWL HABITAT, S. EXEC. DOC. No. 9922 (1986).

3 George Bush, United Nations Framework Convention on Climate Change, S. TREATY Doc. No. 102-38 (1992).

4 Kyoto Protocol to the United Nations Framework Convention on Climate Change, Dec. 11, 1997, 37 ILM 22 (entered into force Feb. 16, 2005).

5 Paris Agreement to the United Nations Framework Convention on Climate Change, Dec. 12, 2015, T.I.A.S. No. 16-1104 (entered into force Nov. 4, 2016).

6 Directive 2009/147/EC of the European Parliament and of the Council of 30 November 2009 on the Conservation of Wild Birds, 2009 O.J. (L 20), 7; Council Directive 92/43/EEC of 21 May 1992 on the Conservation of Natural Habitats and of Wild Fauna and Flora, 1992 O.J. (L 206), 7. 


\section{IMPACT OF CLIMATE CHANGE ON LAKES AND} ADAPTATION MEASURES NEEDED TO REDUCE IMPACTS

The IPCC's SR15 gives the latest overview of climate change impacts on lakes and shows information for high-risk lakes, like reduced water availability, floods, altered water quality, salinization, and ecosystem change leading to loss of biodiversity. Impacts can vary quite substantially from region to region. In some regions, the water levels of lakes are falling, while in others, lakes are flooding. The biggest impact globally is probably reduced water availability. This has been an ongoing trend even without climate change:

Owing to changes in climate and water consumption behaviour, and particularly effects of the spatial distribution of population growth relative to water resources, the population under water scarcity increased from 0.24 billion (14\% of the global population) in the 1900 s to 3.8 billion (58\%) in the 2000s. In that last period (2000s), 1.1 billion people (17\% of the global population) who mostly live in South and East Asia, North Africa and the Middle East faced serious water shortage and high water stress. ${ }^{7}$

It is expected that this situation will become worse, mainly due to further changes in population but also due to climate change, even when limited to a $1.5^{\circ} \mathrm{C}$ increase. ${ }^{8}$

Dozens of pages then describe the findings of a wide range of research into the impact of climate change on ecosystems and animal and plant species. Almost half of the world's local extinctions during the twentieth century can be attributed to climate change. ${ }^{9}$ Species on average lose twenty to twenty-seven percent of their range, even at a $1.5^{\circ} \mathrm{C}$ increase. ${ }^{10}$ Further loss of biodiversity is expected, but difficult to quantify due to the effects of extreme weather events and the role of interactions between species, as well as due to the potential for highly invasive species to become established in new areas as the climate changes. ${ }^{11}$ Some ecosystems with rich biodiversity are likely to disappear altogether. The Amazon jungle, for example, has been shown to be close to its climatic threshold. ${ }^{12}$

\footnotetext{
7 IPCC, supra note 1.

8 Id.

9 Id. at 218.

$10 \mathrm{Id}$.

$11 \mathrm{Id}$.

12 Id. at 221.
} 
The report also describes what is needed to reduce the negative climate change impacts on biodiversity in general, which also applies to lakes. Ecosystem restoration is essential, not just to create more resilience so that biodiversity is better able to adapt to the changing climate, but also for mitigation purposes. Conservation, restoration, and improved land and water management can enhance natural carbon sinks. ${ }^{13}$ This shows that a high level of human intervention into ecosystems, such as lakes, is needed to help biodiversity adapt to the changing climate and to increase natural carbon uptake by vegetation and soils. A wide range of interventions into lakes and the surrounding area needs to be considered, in particular: ${ }^{14}$

- ecosystem restoration or (re-)creation to establish more resilient habitats or corridors and buffer zones to facilitate migration of species to more suitable areas and to increase carbon uptake ("connectivity");

- adjusted management of wetlands and coastal zones (which includes lakes) to create more resilient habitats for wetland and coastal species, increase sequestration, and provide better protection against extreme weather events and floods;

- assisted colonization or relocation of species that cannot survive in their current natural habitat and, if necessary, the creation of new habitats to host these relocated species.

\section{IMPLEMENTING ADAPTATION MEASURES TO PROTECT LAKES FROM CLIMATE CHANGE IMPACTS: THE ROLE OF LAW}

I will now discuss whether these three interventions are mandatory by looking into current international and EU nature conservation and climate change law.

13 Id. at 219.

14 E.g., Arie Trouwborst, Climate Change Adaptation and Biodiversity Law, in Research Handbook on Climate Change Adaptation LaW 298, 301 (Jonathan Verschuuren ed., 2013); Jonathan Verschuuren, Climate Change: Rethinking Restoration in the European Union's Birds and Habitats Directives, 28(4) Ecological Restoration 431, 434-35 (2010); Brendan G. Mackey, James E.M. Watson, Geoffrey Hope, \& Sandy Gilmore, Climate Change, Biodiversity Conservation, and the role of Protected Areas: An Australian Perspective, 9(3\&4) Biodiversity 13 (2008). 


\section{A. Ecosystem Restoration and Connectivity}

Given the current poor state of biodiversity, massive restoration is necessary, even in the absence of climate change. In the EU, for example, an assessment shows that only sixteen percent of legally protected habitats, twenty-three percent of protected species (excluding birds), and fifty-two percent of protected birds are in a favorable condition. ${ }^{15}$ As the EU Wild Birds and Habitats Directives require all protected species and habitats to be in a favorable conservation status, ${ }^{16}$ it is obvious that there is a large gap between what is legally required and the actual situation. Climate change furthers the need for restoring areas and connecting them so they can become an ecological network since the impact of climate change on species viability correlates with the degree of connectedness of that specie's habitat. ${ }^{17}$ Connectivity conservation has been developed as an important conservation tool aimed at restoring or maintaining the functional integrity of natural ecosystems and ecosystem processes, which includes the spatial arrangements and elements needed to allow for connectivity and the natural movement of species and species populations across their distribution ranges. ${ }^{18}$ Connectivity conservation is expected to be a global response to climate change, both for adaptation and mitigation. ${ }^{19}$

Legal instruments relevant to achieve this goal are quite diverse as they can be found in planning law, protected areas law, sustainable resource use law, and water law, as well as in property law, private law, and voluntary arrangements. As connectivity conservation needs to take place at different scales - from local, provincial, and national levels, to regional and even continental level - the use of multiple legal instruments at these various governance levels needs to be carefully orchestrated. To give an example: the Great Eastern Ranges corridor in eastern Australia is 3,600 kilometers long and cuts across a large number of state and local jurisdictions, in addition to being subject to federal jurisdiction. ${ }^{20}$ Part of

15 European Commission, The State of Nature in the EU, 7, 27 (EU 2015).

16 See generally, Council Directive 2009/147/EC, art. 4, 2009 O.J. (L 20); Council Directive 92/43/EEC, art. 6, 1992 O.J. (L206).

17 B.S.J. Nijhof, C.C. Vos, A.J. van Strien, Indicators for the Convention on Biodiversity 2010: Influence of Climate Change on Biodiversity, WOT Natuur \& Milieu 2007 at 15.

18 Barbara Lausche et al., The Legal Aspects of Connectivity Conservation. A Concept Paper. IUCN Environmental Policy and Law Paper No. 85 - Vol. 1 (IUCN 2013) 9.

19 Id. at 32-34.

20 David Farrier \& Melissa Harvey, 'The Great Eastern Ranges Initiative, Australia' in D. Farrier et al. (eds.), The Legal Aspects of Connectivity Conservation. Case Studies (IUCN Environmental Policy and Law Paper No. 85 - Vol. 1 (IUCN 2013) 1, 15. 
the designated corridor has protected areas status, part is state-owned land, and almost half is privately-owned land. Besides individual landowners, such as farmers, local communities and indigenous peoples also own land or have rights to use land or natural resources grounded in constitutions, customary law, or traditional practice, as well as legislation. ${ }^{21}$

International biodiversity-related conventions do not refer to climate change in their legal texts, and generally do not have explicit requirements aimed at connectivity conservation. ${ }^{22}$ Under several of these conventions, however, the parties did adopt decisions related to climate change and connectivity. A prime example is a resolution adopted by the COP of the Convention on Migratory Species, ${ }^{23}$ in which parties are invited to:

[U]ndertake concerted efforts to integrate protected areas into wider landscapes and sectors, including through the use of connectivity measures such as the development of biological corridors, where appropriate, and the restoration of degraded habitats and landscapes in order to address the impacts of and increase resilience to climate change. ${ }^{24}$

Of all biodiversity-related international legal instruments, the parties to the Bern Convention on the Conservation of European Wildlife and Natural Habitats probably have discussed most the need to take restoration and connectivity measures in order to help biodiversity adapt to the changing climate. ${ }^{25}$ Not only did the Bern Convention's Standing Committee adopt a recommendation to establish "networks of interconnected protected areas (terrestrial, freshwater, and marine) and intervening habitat mosaic to increase permeability and aid gene flow" in $2008,{ }^{26}$ but it also adopted detailed and comprehensive guidance on broader issues related to biodiversity and climate change one year later.

21 Lausche et al., supra note 18 , at 46.

22 For an elaborate discussion of the various provisions of the CBD, the CMS, the Ramsar Convention, the world Heritage Convention, and others that do have relevance for connectivity conservation, see Lausche et al., supra note 18, at 57-70. See also Arie Trouwborst, 'International Nature Conservation Law and the Adaptation of Biodiversity to Climate Change: a Mismatch?' (2009) 21(3) Journal of Environmental Law 419-442.

23 Convention on the Conservation of Migratory Species of Wild Animals, Jun. 23, 1979, 1651 U.N.T.S. 333.

24 Arie Trouwborst, Countering Fragmentation of Habitats Under International Wildlife Regimes, in ReSEARCH HANDBOOK ON BIODIVERSITY AND LAW 219, 228 (Michael Bowman et al., 2016).

25 Convention on the Conservation of European Wildlife and Natural Habitats, Sept. 19, 1979, 1284 U.N.T.S. 209.

26 Convention on the Conservation of European Wildlife and Natural Habitats, Standing Comm., Recommendation No. 135 on Addressing the Impacts of Climate Change on Biodiversity, § II(3)(c), CounCIL OF EUR. (November 26, 2009). 
This guidance goes beyond connectivity conservation. It also calls upon the parties to the convention to:

[C]arry out an integrated management of the wider countryside to alleviate the overall pressure on biodiversity and facilitate movement of species between conservation areas, as species dispersal is likely to be the most important mechanism of species adaptation to climate change. ${ }^{27}$

In 2012, another recommendation on climate change and biodiversity was adopted, which, among other things, calls upon the states to:

[T] ake further steps to develop ecological networks, to promote and enhance the permeability of landscapes generally, and also enhance their protected areas networks, as appropriate, by increasing the extent of existing sites, designating new sites and establishing buffer zones, and ensuring they are sustainably and adaptively managed. ${ }^{28}$

Currently, reporting guidelines are being drafted to ensure harmonized reporting by the states on their climate-change-related biodiversity conservation measures. ${ }^{29}$ Furthermore, existing obligations in these conventions can be interpreted to (implicitly) stimulate the adoption of restoration and connectivity measures. ${ }^{30}$

In the EU, the Wild Birds and Habitats Directives do seem to-more or less implicitly_require restoration measures to be implemented in case of habitats or species not being in favorable conservation statuses. ${ }^{31}$ Both Directives, however, lack specificity regarding restoration and do not require member states to adopt robust restoration policies. ${ }^{32}$ Furthermore, there is no legally binding obligation to establish connectivity between

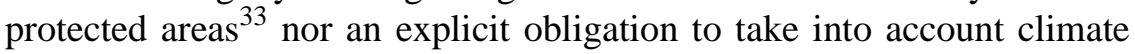

27 Convention on the Conservation of European Wildlife and Natural Habitats, Standing Comm., Recommendation No. 143 on Further Guidance for Parties on Biodiversity and Climate Change, § III(4)-(6), CouncIL of Eur. (November 27, 2008).

28 Convention on the Conservation of European Wildlife and Natural Habitats, Standing Comm., Recommendation No. 159 on the Effective Implementation of Guidance for Parties on Biodiversity and Climate Change, CounCIL OF EUR. (November 30, 2012), https://rm.coe.int/1680746755.

29 See Convention on the Conservation of European Wildlife and Natural Habitats, Standing Comm., Proposed Guidelines for Reporting by Parties, CouncIL of Eur. (May 22, 2017), http://rm.coe.int/inf13e-2017-proposed-guidelines-for-reporting-1st-meetingrestricted-g/16807174f6.

30 Trouwborst, supra note 14 , at 314-21

31 See Verschuuren, supra note 14, at 432-34.

32 Id. at 436-37.

33 Article 10 of the Habitats Directive only gently invites member states to implement connectivity in spatial planning decisions. See Jonathan Verschuuren, Connectivity: Is 
change impacts on biodiversity in any other way. ${ }^{34}$ Yet, one can also conclude that the current provisions do not hinder biodiversity related climate change adaptation policies and, again implicitly, require taking climate change impacts into account since these impacts determine the conservation status of species and habitats. ${ }^{35} \mathrm{~A}$ glimmer of hope is provided by the Court of Justice of the EU in its Alto Sil decision where the court found that protecting connectivity can be a legal requirement in case this is necessary for the maintenance of a protected species. ${ }^{36}$

Under international climate law, connectivity conservation can emerge under several Kyoto Protocol or Paris Agreement instruments. National Adaptation Plans ("NAP") can mention connectivity conservation as an adaptation tool. ${ }^{37}$ However, the NAPs that have been submitted to the UNFCCC's secretariat—so far-hardly mention connectivity conservation in general, let alone with a focus on lakes. An exception, albeit with a focus on forests, is the Brazil NAP, which explicitly sets as a target to "strengthen measures for conservation, recovery and sustainable use of biodiversity, aimed at increasing connectivity between remnants of ecosystems and consolidation of Conservation Units, with a view to promoting integrated landscape-scale forest management and reducing the vulnerability of biological resources" and to "strengthen policies and actions for conservation of aquatic ecosystems, providing maintenance of connectivity among such environments." 38

The second international climate change law anchor point for connectivity measures is the Nationally Determined Contributions ("NDC"). ${ }^{39}$ States can choose to increase sequestration through restoration

Natura 2000 Only an Ecological Network on Paper?, in THE HaBITATS DiRECTIVE IN ITS EU EnVironmental Law Context: European NAture's Best Hope? 285, 299 (CharlesHubert Born et al. eds., 2015).

34 See Verschuuren, supra note 14, at 435-36.

35 Arie Trouwborst, The Habitats Directive and Climate Change: Is the Law ClimateProof?, in The Habitats Directive in ITs EU ENVIRONMENTAL LAW CONTEXT: EUROPEAN NATURE's BeST HoPe? 303, 323 (Charles-Hubert Born et al. eds., 2015); See Verschuuren, supra note 14, at 297-98.

36 See European Commission V. Kingdom of Spain, Case C-404/09, E.C.R. I-11853, II 148-52 (2011).

37 See Paris Agreement to the United Nations Framework Convention on Climate Change, art. 7, I[ 9, Dec. 12, 2015, T.I.A.S. No. 16-1104 [hereinafter Paris Agreement].

38 Braz. Ministry of Env't, National adaptation Plan to Climate Change, Sectoral AND Thematic Strategies, Vol. II 49 (2016).

39 Paris Agreement, supra note 37, at art. 3. 
and connectivity measures. Generally, however, the NDCs submitted under the Paris Agreement do not mention restoration or connectivity. ${ }^{40}$

A third international climate law instrument useful for restoration and connectivity actions is the Clean Development Mechanism ("CDM"). ${ }^{41} \mathrm{~A}$ nice example, again with a focus on forests, is a project in Costa Rica aimed at increased carbon sequestration in small and medium farms through restoration of deforested lands, contributing to creating a diverse landscape, to connecting forest patches in the project area, and to creating habitats for biodiversity protection, especially small mammals and birds. ${ }^{42}$ Unfortunately, there also are examples of CDM projects with negative impacts on connectivity, mainly through large energy infrastructure projects such as hydropower projects and wind farms. Rules have been set within the CDM mechanism to assess and mitigate potential negative impacts on biodiversity. ${ }^{43}$

A fourth relevant international climate law instrument is the various international climate change funds under the UNFCCC, Kyoto Protocol, and Paris Agreement allow for restoration and connectivity actions to be financed by the international community. Taking the Green Climate Fund as an example, the list of approved projects contains several examples where climate change adaptation and mitigation and biodiversity conservation go hand in hand. In Paraguay for instance, a project by the Food and Agriculture Organization ("FAO") is financing carbon sequestering on farmland, which supports local households to diversify their agricultural production to enhance their resilience to climate change impacts. This project, among other things, will restore natural forests for

40 Assessment by author of NDCs available in online NDC Registry. NDC Registry, United Nations Framework Convention on Climate Change, https://www4.unfccc.int/sites/NDCStaging/Pages/All.aspx (last visited Feb. 4, 2020).

41 Kyoto Protocol to the United Nations Framework Convention on Climate Change, art. 12, Dec. 10, 1997, 2303 U.N.T.S. 162; Paris Agreement, supra note 37, at art. 6, II 4.

42 Carbon Development Mechanism Executive Board, Carbon Sequestration in Small and Medium Farms in the Brunca Region, Costa Rica (COOPEAGRI Project), UNITED Nations Framework Convention on Climate Change 2-3 (Mar. 16, 2012), https://cdm.unfccc.int/filestorage/e/y/GVF1L4SX0O6MJ935WAUREBDHCIK8NZ.pdf/ PDD\%20Coopeagri.pdf?t=UGt8cTU3aXgwfDA2J-KoAqP35Ga_OOYGfL8w.

43 An analysis of the environmental impacts of the proposed project must be carried out and include impacts on biodiversity and natural ecosystems and impacts outside the project boundary. CDM Project Standard for Project Activities Version 2.0, CDM-EB93A04-STAN, United Nations Framework Convention on Climate Change, Il 165 (Nov. 29, 2018), https://cdm.unfccc.int/filestorage/e/x/t/extfile-20181221092046529-Reg_stan0 4v02.pdf/Reg_stan04v02.pdf?t=Q3V8cTU3a2ExfDDmkFzxaiwKueLhqZmPXMDN. 
watershed and riparian zone protection and for biodiversity conservation corridors. $^{44}$

\section{B. Adjusted Management}

There are several distinguishable stages of adjusted wetland management. First adaptation actions should focus on building lake and wetland resilience to predicted climate change impacts through protecting or restoring the ecological character. ${ }^{45}$ When threats are exacerbated by climate change, more transformative adaptation options may be required to protect highly valued wetlands such as ecological-engineering techniques that promote in situ transformation-e.g., over-restoration such as planting riparian zones with fast-growing, high-shade species. Such transformative adaptation actions entail a magnified risk to non-targeted assets and services, as well as a higher degree of failure, and thus should be implemented with safety margins and regular reviews. ${ }^{46}$ Also, temporarily suspending fishing activities after the occurrence of a natural disaster to help recover fishery resources, ${ }^{47}$ reducing the maximum sustainable yield, and closing off areas for fishing or other human activities so as to allow for species recovery can be relevant for lakes. ${ }^{48}$

Legal instruments needed for such actions are not just nature conservation law instruments, but also instruments from water law and planning law. In addition, instruments from fisheries law require implementing the measures just mentioned or adjusting fishing permits to changed distribution of fish stocks. ${ }^{49}$

Such actions already received a lot of attention under various international and EU legal instruments over the past fifteen years. The Ramsar Convention bodies have adopted many COP resolutions, guidelines, handbooks, and policy notes on climate change. A text search of the more than 5,500 documents available through the Ramsar Convention's website shows that a stunning total of over 2,200 documents

44 Funding Proposal, FP062: Poverty, Reforestation, Energy and Climate Change Project (PROEZA), GREEN CLIMATE Fund 20 (Mar. 16, 2018), https://www.greenclimat e.fund/sites/default/files/document/funding-proposal-fp062-fao-paraguay.pdf.

45 C.M. Finlayson et al., Policy Considerations for Managing Wetlands Under a Changing Climate, 68 MARINE AND FreShWATER RESEARCH 1803, 1808 (2017).

46 Id. at 1809.

47 Dana D. Miller et al., Adaptation Strategies to Climate Change in Marine Systems 24(1) Global Change Biology e1 (2017).

48 See generally Rosemary Rayfuse, Climate Change, Marine Biodiversity and International Law, in RESEARCH HANDBOOK ON BIODIVERSITY AND LAW 123 (Michael Bowman et al. eds., 2016).

49 Miller et al., supra note 47, at e10. 
refer to "climate change." 50 This indicates that wetland conservation and climate change adaptation and mitigation are now completely intertwined. Following the adoption of a COP resolution in 2002, the obligation under the Ramsar Convention to formulate and implement planning so as to promote the conservation of designated wetlands now has to focus on managing wetlands with the aim to increase their resilience to climate change and extreme climatic events. ${ }^{51}$ Research shows that this means that wetland management should mainly focus on accommodating and compensating for climate change, rather than accepting or avoiding impacts, and on protecting wetland functions and ecosystem services rather than just on the conservation of certain species. ${ }^{52}$ Furthermore, wetland management has to rely on a concerted effort by all available policy instruments, at multiple scales and across sectors. ${ }^{53}$ For the EU, this implies, for example, using management plans for Natura 2000 sites under the Wild Birds and Habitats Directives, ${ }^{54}$ river basin management plans under the Water Framework Directive, ${ }^{55}$ and Flood Risk Management Plans under the Floods Directive. ${ }^{56}$

\section{Assisted Colonization of Endangered Species}

With the climate changing, so is the distribution of species. Generally, the distribution of species is shifting to higher latitudes and altitudes. These changes occur around the world and with all types of species, from birds and butterflies to trees. ${ }^{57}$ Climatic changes, however, occur at such a pace that not all species are able to keep up or, sometimes, simply cannot reach new habitats - e.g. because there is no higher altitude nearby or because a sea or other natural or human-made barrier blocks the

50 Search Results for "Climate Change", RAMSAR, https://ramsar.org/search (check the "Documents" box and search for "climate change" in the search bar) (last visited Apr. $23,2020)$.

51 See Trouwborst, supra note 14, at 308.

52 Finlayson et al., supra note 45, at 1811.

$53 \mathrm{Id}$.

54 European Commission, Guidelines on Climate Change and Natura 2000, 5 (EU, 2013).

55 Council Directive 2000/60, art. 1, 2000 O.J. (L 327) 5-6 (EC); EUROPEAN COMMISSION, COMMON IMPLEMENTATION STRATEGY FOR THE WATER FRAMEWORK DIRECTIVE (2000/60/EC) 2 (2009).

56 Council Directive 07/60, art. 1, 2007 O.J. (L 288) 27, 29 (EC); See also Katrien Debeuckelaere \& Gretta Goldenman, Climate Change, the EU Floods Directive and Biodiversity Protection, in IUCN ACAD. OF ENVTL. L. SERIES, BIODIVERSITY AND CLIMATE Change: Linkages at InTERnAtional, NATiOnAl AND Local LeVEls 305-27 (Frank Maes et al. eds., 2013).

57 Trouwborst, supra note 14 , at 299-00. 
journey to a higher latitude. Also, many species are already vulnerable due to other non-climatic stressors such as land clearing, habitat loss, and invasive species; they are not resilient enough to be able to settle new areas. $^{58}$

In order to help species settle into new areas,- and thus saving the species from extinction-humans may physically relocate specimens to new areas. This is called conservation introduction, assisted migration or assisted colonization, and is already happening at a small scale around the world. In Canada, for example, tree seeds are allowed to be planted at higher latitudes after taking into account the expected temperature when these trees are fully grown in sixty to eighty years from now. Research is underway to develop a full-fledged policy on assisted migration of tree species. $^{59}$

Such conservation introductions, or assisted migration, often is contrary to invasive species legislation-like the Convention on Biological Diversity - that aims to protect native species against alien intruders in a given area. ${ }^{60}$ Furthermore, nature conservation law may hamper catching and relocating specimens of an already endangered species from its natural habitat. These and other legal issues become especially complex in cases of relocation across national or subnational jurisdictions. Yet, there is not much attention for this topic in international biodiversity law. Under the European Wildlife Convention, the 2012 Standing Committee's Recommendation on climate change and biodiversity calls upon the parties to follow the example set by the United Kingdom and implement measures for the assessment of introductions that consider the projected impacts of climate changes on species' invasion potential. ${ }^{61}$

Under the EU Habitats Directive, assisted colonization seems to be possible should such an operation be necessary to ensure a species' survival. As this likely will constitute the introduction of a non-native species, a prior assessment of the consequences for the species that are

58 Id. at 300-01; Phillipa C. McCormack, Conservation Introductions for Biodiversity Adaptation under Climate Change, 7:2 TRANSNAT'L ENVTL. L. 323, 325-326 (2018).

59 For example, in British Columbia. See Assisted Migration Adaptation Trial, PROvinCE OF BRITISH COLUMBIA, https://www2.gov.bc.ca/gov/content/industry/forestry /managing-our-forest-resources/tree-seed/forest-genetics/seed-transfer-climatechange/assisted-migration-adaptation-trial (last visited Jan. 30, 2020); M. Johnston, Vulnerability of Canada's Tree Species to Climate Change and Management Options for Adaptation: An Overview for Policy Makers and Practitioners, CANADIAN COUNCIL OF FOREST MinISTERS (2009), https://cfs.nrcan.gc.ca/publications?id=30276.

60 Convention on Biological Diversity, art. 8, June 5, 1992, 31 I.L.M. 822.

61 Standing Committee Recommendation No. 159, supra note 28. 
native to the colonized area seems to be required under Article 22(b). ${ }^{62}$ According to this provision, introduction cannot "prejudice natural habitats within their natural range or the wild native fauna and flora." The wording of this provision shows that, again, this provision does not explicitly focus on climate change adaptation. It may very well be the case that the entire habitats and many species of existing flora and fauna are changing or disappearing, in which case multiple species and interacting ecological components may need to be introduced. ${ }^{64}$ For these and other reasons, jurists like Phillipa McCormack convincingly show that a new legal framework is required that guides assisted relocations that are part of a biodiversity adaptation strategy. ${ }^{65}$

Assisted colonization may also infringe on the EU Invasive Alien Species Regulation ("IAS Regulation"). ${ }^{66}$ The IAS Regulation does not apply to species changing their natural range without human intervention in response to climate change. ${ }^{67}$ It can be assumed, therefore, that species changing their natural range with human intervention do fall within the scope of the IAS Regulation.

However, invasive alien species that are not alien to the territory of the Union (excluding the outermost regions) cannot be placed on the EU's list of invasive alien species of Union concern against which measures need to be taken. ${ }^{68}$ It is, therefore, likely the IAS Regulation does not impede assisted relocation actions for most, if not all, of the species for which such actions would be considered in the future.

\section{CASE STUDY: LAKE IJSSEL IN THE NETHERLANDS}

I will now assess whether and to what extent these adaptation measures are applied in practice by performing a case study of Lake IJssel (IJsselmeer) in the Netherlands, a protected lake under the Ramsar Convention and the EU's Natura 2000 framework. The aim is to also discover important legal conditions that have to be met for the adaptation policy to be effective.

62 See Trouwborst, supra note 35, at 319-21; Council Directive 92/43/EEC, art. 22(b), 1992 O.J. (L206).

${ }^{63}$ Council Directive 92/43/EEC, supra note 62, at art. 22(b).

64 See generally McCormack, supra note 58, at 342.

65 See id.

66 Council Regulation 1143/2014, On the Prevention and Management of the Introduction and Spread of Invasive Alien Species, 2014 O.J. (L 317) 35.

67 Id. at ch. 1, art. 2(2)(a).

68 Id. at ch. 1, art. 4(3)(a). 


\section{A. The Creation of Lake IJssel}

Lake IJssel only became an inland fresh water lake in 1932, when the former Southern Sea (Zuiderzee) was closed off from the North Sea through the construction of a dam, called the Closure Dam (Afsluitdijk). ${ }^{69}$ Originally, the lake was a sea arm, part of the estuary of the IJssel and Vecht rivers consisting mainly of marshes and shallow salt and brackish tidal waters. The sea arm was closed off from the North Sea in order to end regular floods that were occurring in the area and to create new agricultural lands to improve food security. After the construction of the dam, parts of the new lake area were reclaimed and converted into land. This land was not only used for agriculture, but also for new cities in order to reduce population pressures in the nearby Amsterdam urban area. The remaining water area became a series of interconnected inland lakes, all of which are now protected areas under both the Ramsar Convention and the EU Wild Birds and Habitats Directives. ${ }^{70}$ Lake IJssel became the Netherlands' most important freshwater reservoir for drinking water and agricultural irrigation. It is the biggest freshwater area in northwestern Europe.

\section{B. Lake IJssel's Poor Conservation Status Exacerbated by Climate Change}

Many of the species and habitat types for which this lake has been designated under the EU Wild Birds and Habitats Directives are not in a favorable conservation status, as required by these important EU biodiversity instruments. ${ }^{71}$ There are several reasons for this. First and foremost, the transition of this area from a coastal marshland area into an artificial freshwater lake had severe consequences for the naturally occurring ecosystems. A new natural equilibrium has not yet been reached. The water of the lake has excessive quantities of sediments and is increasingly low on nutrients and marshes are disappearing. Overfishing,

69 Frits Palmboom, Lake IJssel - The IJsselmeer, in DELTA INTERVENTIONS: DESIGN AND ENGINEERING IN URBAN WATER LANDSCAPES 52-53 (A.L. Nillesen et al. eds., 2016).

70 Eemmeer, Gooimeer, IJsselmeer, Ketelmeer, Vossemeer, Markermeer, IJmeer, Veluwerandmeren and Zwarte Meer. Officially, these are all considered separate lakes, with the IJsselmeer being the largest. In this Article, however, I treat them together under the overall name of Lake IJssel as they are largely (although not entirely) interconnected and all protected under the same legal regimes.

71 See for example this document (in Dutch) that discusses the conservation status of a very long list of habitat types and species that require protection under EU law in part of the Lake IJssel area. See ONTWERPBESLUIT IJSSELMEER, available at https://www .natura2000.nl/gebieden/flevoland/ijsselmeer/ijsselmeer-archief. 
increasing pressure by recreation, and active human manipulation of water levels to allow for intensive farming and urbanization have turned the lake essentially into a big tub with muddy, empty water. The number of fish and other water organisms have declined tremendously, as has the number of birds.

Climate change is exacerbating this already poor situation through: ${ }^{72}$

- increasing water temperatures (leading to reduced oxygen levels and increased harmful algae blooms),

- increasing intrusion of alien invasive species (such as the quagga mussel, which affects natural algae and native mussel populations, as well as power and water treatment infrastructure),

- increasing peaks both in low water levels caused by droughts and highwater levels caused by increased precipitation and increased river water run-off,

- bigger impact of several chemicals, such as phosphates from agricultural run-off in case of highwater situations, and chloride from upstream salt mines in France in case of low water levels in summer,

- bigger impacts from recreation due to longer recreation seasons, and

- increasing flood risks due to accelerated sea level rise, which will make it increasingly difficult to flow off river water into the (higher) North Sea.

\section{Legal Requirement to Restore the Degraded Lake IJssel}

Lake IJssel was designated as a wetland of international importance under the Ramsar Convention in 2002 and as a protected area under the EU Wild Birds and Habitats Directives' Natura 2000 network in 2010. The EU Directives contain much stricter legal obligations than the Ramsar Convention and have much more legal force as the EU legislation is directly binding under domestic law of the EU Member States and there is

72 R. Loeve ET AL., KlimaAtVERANDERING EN WATERKWAliteit (2006), https://www.futur ewater.nl/downloads/2006_Loeve_FW58.pdf; DeltareS, MogeliJKe GEVOLGEN VAN VERSNELDE ZEESPIEGELSTIJGING VOOR HET DELTAPROGRAMMA. EEN VERKENNING (2018),

https://www.deltacommissaris.nl/binaries/deltacommissaris/documenten/publicat ies/2018/09/18/dp2019-b-rapport-deltares/DP2019+B+Rapport+D eltares.pdf; IJsselmeer region, DELTACOMMISSARIS, https://www.deltacommissaris.nl/delt aprogramma/gebiedenen-generieke-themas/ijsselmeergebied. 
an enforcement mechanism through the Court of Justice of the EU. As a consequence, the Ramsar Convention has lost much of its relevance for those areas that have also been designated under the EU's Natura 2000 network (which is the case for all Ramsar sites in the Netherlands). ${ }^{73} \mathrm{I}$ will, therefore, primarily focus this section on the restoration obligations under EU nature conservation law.

For areas designated under the EU Wild Birds and Habitats Directives, conservation goals aimed at the specific habitat types and species for which these areas have been designated must be set. As most of the habitat types and species for which the Lake IJssel has been designated under the Natura 2000 network are not in a favorable conservation status, many conservation goals are aimed at increasing populations directly or at increasing acreage for certain habitat types. The latter can only be achieved through restoration; hence restoration is a legal requirement for Lake Ijssel. ${ }^{74}$ In order to comply with this requirement, the management plans for the lake have adopted a wide range of restoration actions, some of which focus on the climate change related measures discussed above (ecosystem restoration and connectivity, adjusted management, assisted colonization). It should be noted that the management plans for Lake IJssel do not just focus on nature conservation, but on all relevant environmental issues. A range of legal frameworks apply to the lake partly stemming from the EU, such as laws on water quality and flood management, and partly from the domestic level, such as laws on polluted water soils and spatial planning. Furthermore, all of these plans are part of a broader development policy for the Lake Ijssel area, called "Agenda Lake IJssel area 2050," covering not just nature conservation, but also water safety, drinking water supply, water quality, fisheries, sustainable energy, infrastructure and transport, sand extraction, landscape conservation, culture, recreation, and tourism. ${ }^{75}$

\section{Restoration Plans for Lake IJssel}

The first phase of the plans, which runs from 2017 until 2023, primarily aims at stopping the decline in quality and quantity of habitat types and species. To achieve that, the current plan has five main goals: ${ }^{76}$

73 See generally Jonathan Verschuuren, The Case of Transboundary Wetlands under the Ramsar Convention: Keep the Lawyers Out, 19 COLO. J. INT'L ENVTL. L. \& PoL'y 49 (2008).

74 See supra Section II.A.

75 AgENDA IJsSELMEERGEBIED 2050, https://www.agendaijsselmeergebied2050.nl/.

76 Rijkswaterstaat: Ministerie van Infrastructudr en Milieu, Natura 2000 BehEeRPlan IJSSELMEERGEBIED 2017-2023: PublieKSSAMENVATTING (2017). 
- improvement of marshes on the edges of the lake for breeding reed birds,

- creation of new sandy breeding areas for water birds that breed on sandy beaches,

- improvement of availability of food for birds,

- improvement and enlargement of certain habitat types, and

- more space and tranquility for birds.

Most, if not all, of these goals align with the climate change related adaptation measures that have been discussed above, especially restoration, connectivity, and adjusted management. It is remarkable, though, that climate change is not mentioned much in the various documents detailing the restoration requirements for Lake IJssel. I assume that this is because of the already poor conservation status that requires urgent action even without climate change.

The following table lists some of the restoration measures that contribute to climate change adaptation for the lake-despite the fact that they were not specifically proposed with that focus: ${ }^{77}$

77 Taken from a range of documents on the management of the Natura 2000 sites of Lake Ijssel. RijkswaterstaAt: Ministerie Van InfrastructuUr en Milieu, Natura 2000 BEHEERPLAN IJSSELMEERGEBIED 2017-2023: ALGEMEEN DEEL (2017), https://www.rwsnatura2000.nl/gebieden/ijsselmeergebied/ijss_documenten/HandlerDown loadFiles.ashx?idnv=1631335; RIJKSWATERSTAAT: MINISTERIE VAN INFRASTRUCTUUR EN MiLieU, NATURA 2000 BEHEERPLAN IJSSELMEERGEBIED 2017-2023: IJSSELMEER (2017), https://www.rwsnatura2000.nl/gebieden/ijsselmeergebied/ijss_documenten/HandlerDown loadFiles.ashx?idnv=1631389; RIJKSWATERSTAAT: MINISTERIE VAN INFRASTRUCTUUR EN MiliEu, NATURA 2000 BEHEERPLAN IJSSELMEERGEBIED 2017-2023: KETELMEER \& VOSSEMEER (2017), https://www.rwsnatura2000.nl/gebieden/ijsselmeergebied/ijss_documenten/HandlerDown loadFiles.ashx?idnv=1631348; RIJKSWATERSTAAT: MINISTERIE VAN INFRASTRUCTUUR EN Milieu, NATURA 2000 BEHEERPLAN IJSSELMEERGEBIED 2017-2023: MARKERMEER \& IJMEER (2017), https://www.rwsnatura2000.nl/gebieden/ijsselmeergebied/ijss_documenten/HandlerDown loadFiles.ashx?idnv=1631349; RIJKSWATERSTAAT: MINISTERIE VAN INFRASTRUCTUUR EN MiLIEU, NATURA 2000 BEHEERPLAN IJSSELMEERGEBIED 2017-2023: VELUWERANDMEREN (2017),

https://www.rwsnatura2000.nl/gebieden/ijsselmeergebied/ijss_documenten/HandlerDown loadFiles.ashx?idnv=1631351; RIJKSWATERSTAAT: MINISTERIE VAN INFRASTRUCTUUR EN Milieu, NATURA 2000 BeHEERPLAN IJSSELMEERGEBIEd 2017-2023: ZwARTE MEER (2017),

https://www.rwsnatura2000.nl/gebieden/ijsselmeergebied/ijss_documenten/HandlerDown loadFiles.ashx?idnv=1631352. 


\begin{tabular}{|c|c|}
\hline \multicolumn{2}{|c|}{ Ecosystem restoration and connectivity } \\
\hline Measure & Aim \\
\hline $\begin{array}{l}\text { 1. Replacing artificial, fixed banks } \\
\text { by more natural banks and borders } \\
\text { 2. Creating sandy islands in the main } \\
\text { water body of the lake } \\
\text { 3. Constructing a fish migration river } \\
\text { 4. Opening up old creeks and streams }\end{array}$ & $\begin{array}{l}\text { 1. Gradual transition from water to } \\
\text { land } \\
\text { 2. Increase breeding space for } \\
\text { birds \& help sediment settle } \\
\text { down thus improving water } \\
\text { quality for (shell)fish } \\
\text { 3. Enable migratory fish to } \\
\text { bypass artificial dams } \\
\text { 4. Restore natural connection } \\
\text { between land and water }\end{array}$ \\
\hline \multicolumn{2}{|c|}{ Adjusted management } \\
\hline Measure & Aim \\
\hline $\begin{array}{l}\text { 1. Targeted reed management (keep } \\
\text { young reed plants in some areas, } \\
\text { and perennial reed in others) } \\
\text { 2. Introducing permits for } \\
\text { commercial fishing with } \\
\text { conditions } \\
\text { 3. Banning certain recreational } \\
\text { activities (boasting, kite } \\
\text { surfing) in some areas } \\
\text { 4. Concluding voluntary } \\
\text { agreements with recreational } \\
\text { sector } \\
\text { 5. Adjust water level management to } \\
\text { more natural levels is preferred; } \\
\text { however, this measure is } \\
\text { postponed to later, to be aligned } \\
\text { with water management plans } \\
\text { under climate change }\end{array}$ & $\begin{array}{l}\text { 1. } \begin{array}{l}\text { Enable expansion of various } \\
\text { species of reed birds and reed } \\
\text { mammals }\end{array} \\
\text { 2. Avoid water birds getting } \\
\text { caught in nets and other fishing } \\
\text { gear } \\
\text { 3. Reduce disturbance of protected } \\
\text { birds } \\
\text { 4. Inform and educate the public } \\
\text { so as to achieve less impact on } \\
\text { breeding birds } \\
\text { 5. Establish natural water levels, } \\
\text { plan for climate change related } \\
\text { variations of water levels }\end{array}$ \\
\hline
\end{tabular}

Assisted colonization is not specifically addressed in the management plans. Yet, despite not having a direct connection to climate change, this measure is, to some extent, relevant. In the 1980s, the Eurasian otter became extinct in the Netherlands, mostly due to water pollution in the previous decades. The species, however, was reintroduced and is now back as a viable population in the Lake IJssel area. Furthermore, some of the restoration measures do aim to facilitate the natural relocation of species that were not present in the area before. The latter is particularly true for the white-tailed eagle that has colonized the area and has been breeding

78 This table shows some restoration measures that contribute to climate change adaptation for the lake. 
there since 2006. The artificial fish migration river mentioned above helps salmon and other migratory fish to recolonize the lake and the rivers feeding the river. The assisted relocation of soil disturbing fish species from another part of the area to the lake is considered with the aim to improve the quality of the water soil.

\section{E. Enabling Factors for the Restoration Plans for Lake IJssel}

In this section, I will deal with some important enabling factors that determine the success of the plans sketched above: the available financial budget, the role of the various authorities and other stakeholders involved, and the role of the general public.

\section{Financial Budget}

The measures discussed above come at a cost. It is, therefore, important to adopt a multi-annual budget. Otherwise, the risk exists that the plans are not executed, or that implementation stops mid-way. In the restoration plans for the Lake IJssel, implementation costs for each of the measures proposed has been included. The estimated budget consists of two elements: costs for construction or establishment of the restoration measures (once-off costs) and costs for the first ten years of maintenance of the restoration measures. The total amount of once-off implementation costs is between 630 and 1,060 million euro plus between 41 and 89 million euro for maintenance costs for the first ten years. ${ }^{79}$

\section{The Role of the Various Authorities and Other Stakeholders Involved}

The governance structure of Netherlands can be characterized as a decentralized unitary state. This means that central government involves the provinces, municipalities, and water districts in the formulation and execution of its policies. ${ }^{80}$ Hence, consensus building is considered to be of vital importance and the Netherlands has a long tradition of always looking for consensus among all those involved. This tradition dates back to the early coastal defense and land reclamation activities around 1200, predating the establishment of the Dutch State. Such activities were only

79 A. RemmelzwaAl Et AL., PreVerkenning IJsselmeergebied: ACHTERGRONDDOCUMENT PREVERKENNING ECOLOGISCHE KWALITEIT IJSSELMEERGEBIED (2017), https://www.agendaijsselmeergebied2050.nl/binaries/agenda-ijsselmeergebied/do cumenten/rapporten/2018/06/19/preverkenning-ecologie-ijsselmeergebied/Achtergrond document+preverkenning+ecologie+IJsselmeergebied.pdf.

80 Wil Zonneveld, Governing a Complex Delta, in Delta Urbanism: The NETHERLANDS 101, 102 (Han Meyer et al. eds., 2010). 
possible with the collaboration of everyone, and thus through balancing everyone's interests. This has led to the enactment of laws that have a subtle, and somewhat complex, system of joint decision making on such topics as water management, nature conservation, and spatial planning.

As a consequence, many government bodies are involved in the implementation of the restoration plans for Lake IJssel, including:

- central government is responsible for coastal and flood defenses that are of national importance (i.e., all coastal defense systems and flood defense systems of the main rivers), as well as for complying with EU-law requirements (vis-à-vis the European Commission),

- provincial governments are responsible for nature conservation, and for coordinating water management and spatial planning,

- water district boards are responsible for water management (in a broad sense, including water related nature conservation), and

- municipal governments are responsible for local spatial planning.

As the Lake IJssel area is located within four provinces, it has thirtytwo municipalities and six water districts. Additionally, five central government ministries are involved in the broader development plans of the area; intensive collaboration among all of these actors is needed. Such collaboration is coordinated by the Minister of Infrastructure and Water. Also involved in this process are non-governmental stakeholders, such as (agri-) businesses and environmental NGOs. Environmental NGOs actually play an important role, as several NGOs own property within the protected areas.

\section{The Role of the General Public}

Local residents, businesses, and NGOs are also involved through the regular administrative procedures that need to be followed with all government decision making (at all levels) and that require effective public participation and access to justice. Hence, there are public hearings and other forms of public participation and all interested parties have the right to go to court. Thanks to the intensive collaborative decision making processes aimed at reaching consensus (as sketched above), there generally is broad support for the plans once they are adopted. Nevertheless, every administrative decision that is taken to implement the restoration plans can end up in court. Often, court cases focus on the question of whether a certain decision is in compliance with EU law, such as the EU Wild Birds and Habitats Directives.

To enhance public acceptance of the plans, it was decided to choose six so-called ambassador species, or flagship species, that are 
representative of the area and that should all benefit from the measures adopted. These are:

- great reed warbler (endangered species that is characteristic for areas with firm, perennial reed),

- Eurasian otter (reintroduced species sensitive to water pollution),

- white tailed eagle (top predator that recolonized Lake IJssel as of 2006),

- European eel (migratory eel that requires good connections between Lake IJssel area and the North Sea/Atlantic Ocean),

- northern pike (a large predator fish that requires both shallow waters with lots of plants and deep clear waters), and

- black tern (a migratory bird of which more than half of the entire population uses Lake IJssel during migration to and from Africa).

This is an interesting way to move beyond the often rather technical discussions on ecology, hydrology, and climate change and to engage with a wider audience, so as to achieve broad acceptance of the plans.

\section{F. Assessment of the Lake IJssel Restoration Plans}

The restoration measures included in the first management plan for Lake IJssel are important first steps to bringing the ecological quality of the lake back to an acceptable level. Species and habitat types that are in a favorable conservation status are much more resilient to climate change than species and habitat types that are in a poor condition. The measures aimed at increased connectivity, such as the creation of a fish migration river and of new islands in the lake for the sake of nature are spectacular and have had fascinating results even within the first few years since these measures were taken. It is also clear, however, that much more is needed to make the area completely resilient to climate change. Measures aimed at restricting harmful human activities still need to be taken. So far, only some preliminary measures aimed at regulating commercial fishing and recreation were adopted. More restrictions, especially for commercial fishing, are considered necessary which requires redistribution of existing fish permits and closing of certain parts of the lake for fishing. More drastic limitations on shipping and agriculture will follow from restoring natural water levels. Creating more connections with the sea, between the various parts of the lake area, and with the rivers feeding the lake, would also greatly enhance the resilience of the area, but is considered to be risky from a water safety perspective. The current approach of setting small gradual steps towards a more-natural ecosystem seems effective for now, 
but we have to wait and see whether this approach will still work when tough decisions need to be made that are costly and will have clear negative economic side effects.

\section{CONCLUSION}

Throughout the world, lakes are facing deterioration due to intensive economic use. Climate change is exacerbating this situation. The only way forward is through implementing massive ecosystem restoration and connectivity policies, adjusted water management, and policies aimed at assisted colonization of endangered species. Current international and EU law do not explicitly require such policies to be developed and implemented, at least not in a legally binding way. One could easily argue, however, that restoration measures-considering current and future climate change impacts - are required in order to achieve the overarching goals of nature conservation and climate change instruments (biodiversity conservation and climate change adaptation).

The case of Lake IJssel in the Netherlands shows that a long-term concerted effort is needed with a sufficient budget in place to achieve the necessary changes. In this case, the plans are in place and some impressive restoration measures were already taken. Interestingly, many of these measures indeed focus on restoration and connectivity and on adjusted management, although without many references to climate change. This shows that such measures are considered necessary to restore degraded lakes, even in the absence of climate change. Yet, the difficult part of the process, namely the part where vital economic activities are restricted to enhance ecosystem quality, still needs to be discussed. It is unclear whether all government and non-government stakeholders involved will be able to reach consensus on the implementation of such restoration plans. A carefully planned, step-by-step approach, relying on much discussion and consensus building and covering at least ten to twenty years or more seems to be an appropriate way to achieve the required level of restoration.

The legal framework to guide this process is only partly available. This Article sought to research how law can help to implement the necessary climate change adaptation measures for lakes. Key elements of a legal framework that facilitates such measures are:

- Legally binding conservation goals aimed at specific lake habitats and species, such as those set under the EU Wild Birds and Habitats Directives. These goals will guide policy making, policy implementation and testing of specific measures in court. 
- Administrative laws and a legal culture that facilitate collaborate decision making among all levels of government involved, under the guidance and supervision of one authority that bears ultimate responsibility for the process.

- All authorities involved have to rely on a range of legal frameworks to achieve the restoration plans for the lake, such as water laws, spatial planning laws, fisheries laws, agricultural laws, environmental laws, etc. All of these legal frameworks have to enable collaborate decision making as per the previous point.

- Administrative laws and a legal culture that facilitate involvement of non-governmental actors, such as businesses, environmental NGOs, and local residents throughout the entire process.

- Financial budget to implement the policies, including a budget to compensate economic losses of those stakeholders for whom there is no room under the future plans. 